\title{
最近の歯学
}

\section{4. 細胞機能制御}

\section{インターロイキン $1 \beta$ による破骨細胞形成機序の解明 - prostaglandin $\mathrm{H}$ synthase-2 (COX-2) の関与一}

東京医科歯科大学大学院生体制御歯科学系細胞機能制御学講座 佐藤 孝浩, 森田 育男, 室田 誠逸

インターロイキン $1 \beta(\mathrm{IL}-1 \beta)$ はさまざまな生理活 性を有するサイトカインであり，特に炎症性疾患にお いて重要とされている。骨吸収因子である Osteoclast Activating Factor (OAF) が Dewhirst らにより IL-1 $\beta$ として同定され1)，またその骨吸収機序に内因性の プロスタグランディン (PG) が関与することがこれま でに報告されている2)。慢性炎症を伴う関節りウマチ や骨髄腫などにおける骨吸収には常在破骨細胞の活性 化よりはむしろ血液幹細胞から破骨細胞への分化誘導 が注目されているが，IL-1 $\beta$ に上る破骨細胞形成誘導 に対する内因性 $\mathrm{PGE}_{2}$ の役割ならびにその産生機序に ついての詳細な検討はこれまでなされていない。近年 PG 合成酵素である PGH synthase (PGHS) には con stitutive type $の$ PGHS-1 (COX-1) の他に inducible type である PGHS-2 (COX-2) が存在し, 現在その機 能的特性の相違が明らかとなりつつある れわれはマウス骨髄細胞培盖系を用いIL-1 $\beta$ に上り 惹起される破骨細胞形成における PGHS-2 の役割に ついて検討を行った。

IL-1 $\beta$ は用量依存的に破骨細胞形成およびメディ ウム中の $\mathrm{PGE}_{2}$ 量を上昇させ,これらはインドメタシ ン(IND)により抑制された。IL-1 $\beta$ 共存下での $\mathrm{PGE}_{2}$ に上る破骨細胞形成は $\mathrm{PGE}_{2}$ 単独と比較して有意に上 杽し，INDは IL-1 $\beta$ による破骨細胞形成を完全に抑

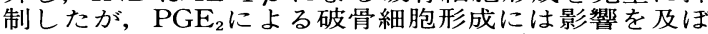
さないことから(図 1)，IL-1 $\beta$ による破骨細胞形成は

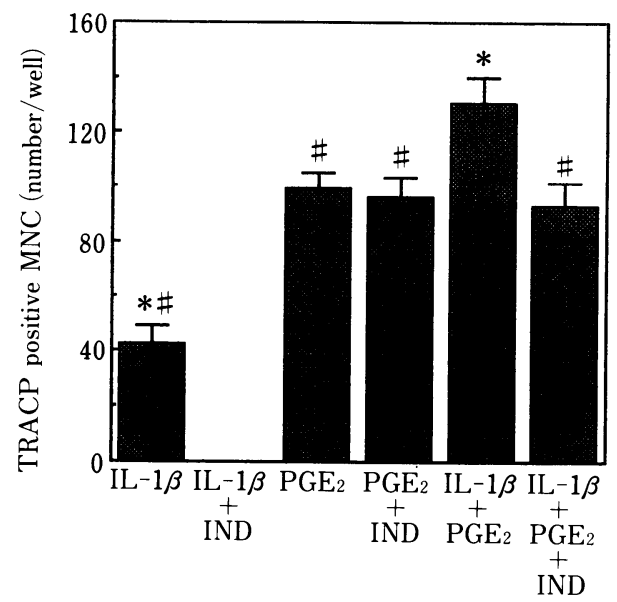

図 $1 \quad \mathrm{PGE}_{2}$ 共存下での IL-1 $\beta$ 誘発破骨細胞形成に 対するインドメタシンの効果

* : $\mathrm{PGE}_{2}$ に対する有意差 $(\mathrm{p}<0.05)$

\# : IL-1 $\beta+\mathrm{PGE}_{2}$ に対する有意差 $(\mathrm{p}<0.05)$

$\mathrm{IL}-1 \beta: 20 \mathrm{ng} / \mathrm{m} l, \mathrm{PGE}_{2}: 1 \mu \mathrm{g} / \mathrm{m} l$, IND : $1 \mu \mathrm{M}$
内因性の $\mathrm{PGE}_{2}$ たすることが示唆された。

IL-1 $\beta$ による $\mathrm{PGE}_{2}$ 産生の経時変化は PGHS-2 mRNAレベルの変化と一致し, $\mathrm{PGE}_{2}$ 産生はシクロへ キシミドにより抑制された。PGHS-2 mRNAレベル の上昇はデキサメサゾン (DEX) により抑制され，ま た DEX は IL-1 $\beta$ に上る破骨細胞形成を用量依存的 に抑制した。さらに PGHS-2 選択的阻害剂であるNS398 は IL $-1 \beta$ による破骨細胞形成を抑制したことか ら（図 2) 骨骵細胞培養系において, IL-1 $\beta$ による破 骨細胞形成は内因性 $\mathrm{PGE}_{2}$ を介した間接的なものであ $\eta, \mathrm{IL}-1 \beta$ による $\mathrm{PGE}_{2}$ 産生および破骨細胞形成誘導 にはPGHS-2 が重要な役割を果たしていることが示 唆された。

\section{文献}

1) Dewhirst, F. E., Stashenko, P. P., Mole, J. E. and Tsurumachi, T. : Purification and partial sequence of human osteoclast-activating factor : identity with interleukin 1 beta. J. Immunol 135:2562-2568, 1985

2) Sato, K., Fujii, Y., Kasono, K., Saji, M., Tsushima, T and Shizume, K. : Stimulation of prostaglandin $E_{2}$ and bone resorption by recom binant human interleukin 1 alpha in fetal mouse bones. Biochem. Biophys. Res. Commun. 138: 618-624, 1986

3) Morita, I., Schindler, M., Regier, M. K., Otto, J. C., Hori, T., DeWitt, D. L. and Smith, W. L. : Different intracellular locations for prostaglan din endoperoxide Hosynthaseo-1 and -2 . J. Biol. Chem. 270 : 10902-10908, 1995.

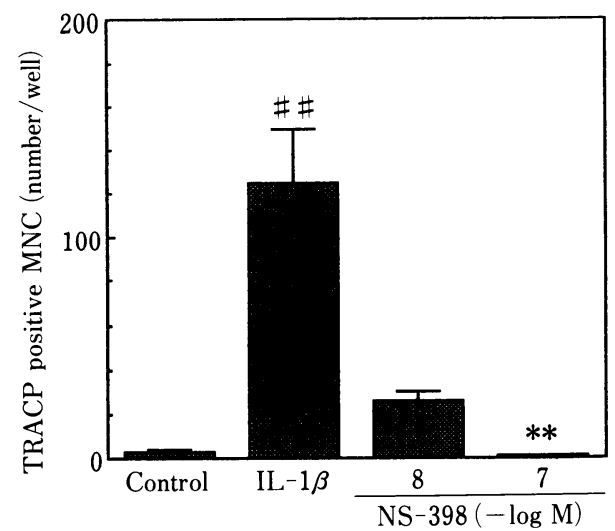

図 2 IL-1 $\beta$ 誘発破骨細胞形成に対する NS-398 の 効果

IL-1 $\beta$ : $20 \mathrm{ng} / \mathrm{m} l, * *$ ：IL-1 $\beta$ に対する有意差 $(\mathrm{p}<0.01)$ ，\#\#：コントロールに対する有意差 $(\mathrm{p}<0.01)$ 